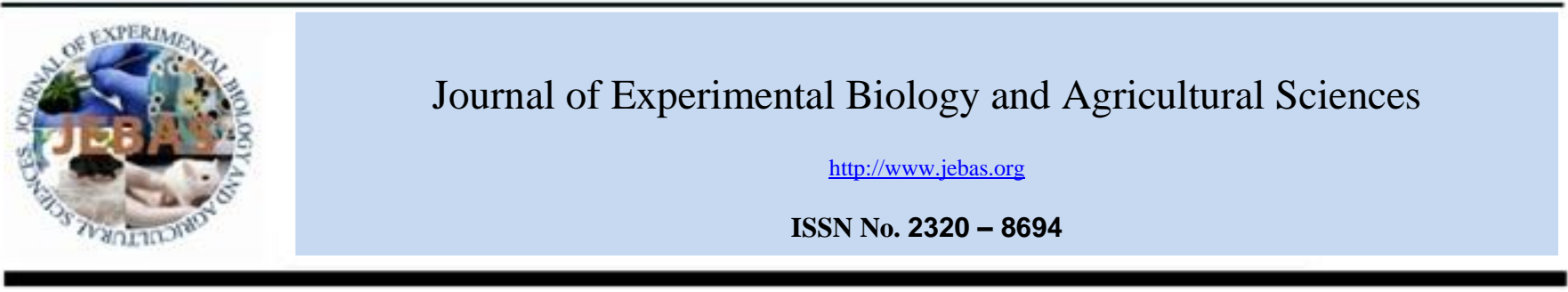

\title{
A COMPARATIVE STUDY OF FATTY ACID EXTRACTION METHODS OF SESAME (Sesamum indicum L.) VARIETIES GROWN UNDER MEDITERRANEAN ENVIRONMENT
}

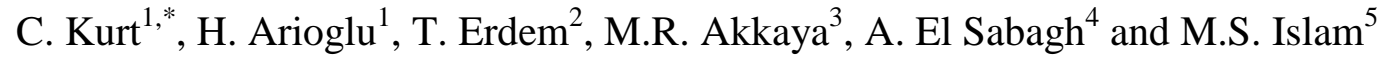 \\ ${ }^{1}$ Cukurova University Dept. of Field Crops in Adana, 01330 Balcali, Turkey \\ ${ }^{2}$ Cukurova University Dept. of Agricultural Machinery in Adana, 01330 Balcali, Turkey \\ ${ }^{3}$ Adana Science and Technology University, Turkey \\ ${ }^{4}$ Department of Agronomy, Faculty of Agriculture, Kafrelsheikh University, Egypt \\ ${ }^{5}$ Department of Agronomy, Hajee Mohammad Danesh Science and Technology University, Bangladesh \\ Received - September 05, 2016; Revision - September 29, 2016; Accepted - October 06, 2016 \\ Available Online - October 07, 2016
}

DOI: http://dx.doi.org/10.18006/2016.4(5S).588.593

\section{KEYWORDS}

Turkish Sesame Oil

Cold Press

Soxhlet Extraction

Fatty Acid

ABSTRACT

Present study was carried out to determine the effects of two oil extraction methods on the composition of oil fatty acid in sesame of some Turkish genotypes.Two oil extraction techniques viz.Cold pressing (CP) and Soxhlet extraction (SE), were compared for the fatty acid composition of 25 Turkish sesame genotype. Higher averaged sesame seed oil yield (54.7\%) was obtained in the SE method than the CP method $(31.1 \%)$. The oil compositions of sesame genotypes were compared and the presence of five main dominated sesame fatty acid components namely palmitic, stearic, arachidic, oleic and linoleic acid was reported. Among these five fatty acid, palmitic (9.38-10.56\%) and stearic acids (4.73-5.12\%) were reported predominant saturated fatty acids while arachidic acid was reported in minimum concentration in sesame oil ranging of 0.52 to $0.59 \%$. Oleic and linoleic acids are the major fatty acids of sesame oil and are reported in large amounts in the oils of all genotypes.The percentage of oleic acid ranged from 37.15 to 41.67 , while this percentage was reported between 42.22 to 45.54 for Linoleic acid. From the results of this study, it can be concluded that the fatty acid profile of the sesame oil was not significantly influenced by oil extraction method.
\end{abstract}

* Corresponding author

E-mail: cemalkurt71@yahoo.com (C. Kurt)

Peer review under responsibility of Journal of Experimental Biology and Agricultural Sciences.

Production and Hosting by Horizon Publisher India [HPI] (http://www.horizonpublisherindia.in/).

All rights reserved.
All the article published by Journal of Experimental Biology and Agricultural Sciences is licensed under a Creative Commons Attribution-NonCommercial 4.0 International License Based on a work at www.jebas.org.

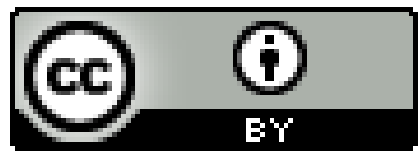




\section{Introduction}

Sesame (Sesamum indicum L.), one of the oldest and very important oil seed crops known, is widely grownin tropical and subtropical areas of the World. Sesame is under cultivation for about 6000 years (Namiki, 1995). Sesame is an excellent source of oil (50\%) and protein (20\%) and is wiedly used as vegetable oil. In sesame, oleic and linoleic acids are the predominant fatty acids and constitutes more than $80 \%$ of the total oil.The high levels of monounsaturated and polyunsaturated fatty acids (MUPA \& PUFA) increase the quality of the oil for human consumption. Moreover, high levels of linoleic acid, MUPA \& PUFA reduce blood cholesterol and play an important role in preventing atheros clerosis (Ghafoorunissa, 1994). Oils with a high content of unsaturated fatty acids are generally more susceptible to oxidation, undergoing rapid degradation and polymerization by free radical mechanisms (Guillen \& Goicoechea, 2008). But, sesame oil has a privilege characteristic such as the presence of the natural antioxidants sesamol, sesamolin, and gammatocopherol, which gives it high oxidative stability (Corso et al., 2010).

Martin \& Leonard (1964) reported that sesame is mostly used for edible purposes such as oil and confectionery. It is also used for various other purposes i.e. manufacture of margarine, soap, paint, perfumes, cosmetics, pharmaceutical products, paints and insecticides and cookies (AlamSarkar et al., 2007). Further, Weiss (2000) suggested that sesame seed contains essential amino and fatty acids specially linoleic acid. It is a good source of vitamins such as vitamin $\mathrm{E}$ and minerals such as calcium and phosphorous and the seed cake is also an important nutritious livestock feed. Sesame seed also contain a group of compounds called lignans which have many health promoting effects (Pathak et al., 2014).

At industrial level, oil extraction is mainly carried out by two methods, viz. cold pressing and solvent extraction (Soxhlet method). Soxhlet method involving the use of $n$-hexane or petroleum ether as extraction solvent, although gives higher oil yield but higher temperature employed in this method may cause some undesirable effects on the quality of oil (Nadeem et al., 2015). Although, cold pressing method of oil extraction gave lower oil yield but mild operational temperature conditions maintain the safety of product quality (Bavec et al., 2007). Cold pressed oils generally exceed refined oils in their nutritional value.

It maintain natural beneficial ingredients of sesame oil such as tocopherols, sterols, carotenoids, and phospholipids which are partially removed as a result of oil refining (Gogolewski et al.,2000; Koski et al., 2003). Considering of the growing concern and demand about the functional and nutritional properties of oils, the present work was therefore designed to evaluate and compare the fatty acid composition of oil extraction methods of some Turkish sesame genotypes.

\section{Materials and Methods}

The experiment was conducted at Adana province of Turkey $\left(35^{\circ} 18^{\prime} \mathrm{E}\right.$ latitude, $37^{\circ} 01^{\prime} \mathrm{N}$ longitude, and $23 \mathrm{~m}$ above sea level) in 2012. Seeds of 25 sesame genotypes viz. 1) Cumhuriyet-99, 2) Tan-99, 3) Kepsut-99, 4) Baydar-2001, 5) Muganl1-57, 6) Orhangazi-99, 7) Gölmarmara, 8) Osmanl1-99, 9) Şanlıurfa-Siverek, 10) Diyarbakır-Merkez, 11) Kahramanmaras, 12) Diyarbakır-Lice, 13) Adana-Kozan-2, 14) Manisa-Salihli, 15) Manisa-Alaşehir, 16) Adana-Ceyhan, 17) Antalya-Kumluca, 18) Adana-Yumurtalık, 19) OsmaniyeKadirli, 20) Muğla-Fethiye, 21) Adana-Karataş, 22) AdanaSarıçam, 23) Balıkesir-Ayvalık, 24) Aydın-Merkez and 25) Adana-Merkez were sown in the second week of June, 2012. The accessions were grown in four row plots of $5 \mathrm{~m}$ row length with a row spacing of $70 \mathrm{~cm}$ and intra-row spacing of $15 \mathrm{~cm}$. Thinning was carried out after 25 days of sowing to secure one plant at $15 \mathrm{~cm}$. Sprinkler irrigation was established immediately after sowing and thereafter used when necessary based on soil and plant conditions. Nitrogen, phosphorus and potassium were applied at a rate of $60 \mathrm{~kg}$ per hectare at sowing as a complete fertilizer. Weedings were carried out by hand weeding and no herbicides were applied during the growing seasons. All the plants were harvested in the last week of September, 2012.

\subsection{Extraction of sesame seed oil}

Sesame seeds were pressed by screw press with a nozzle diameter of $6.8 \mathrm{~mm}$ and a rotational speed of $47 \mathrm{rpm}$. Three replications were performed for each sample, and oil yield was calculated as percentage in weight basis. Sesame seeds were also extracted by soxhlet apparatus to assess the total oil yield.The data were calculated as a mean of three replications. Then the two methods were compared upon the oil yield and oil composition.

\subsection{Gas chromatography (GC) Analyses}

An oil sample of $500 \mathrm{mg}$ was dissolved in $2 \mathrm{ml}$ isooctane followed by $1.5 \mathrm{ml}$ of $0.5 \mathrm{M}$ methanolic $\mathrm{NaOH}$. The tube was then vortexed and held in boiled water for $7 \mathrm{~min}$ and left to cool. Then $2 \mathrm{ml}$ of BF3 (Boron trifluoride) was added, vortexed, and held in boiling water for $5 \mathrm{~min}$ and left to cool. After adding $5 \mathrm{ml} \mathrm{NaCl}$ the tube was vortexed. After centrifugation at $4,000 \mathrm{rpm}$ for $10 \mathrm{~min}$, the top layer was gathered for GC analyses (AOAC, 1984; Ozogul et al., 2011).

The fatty acid (FA) composition was analyzed by GC Clarus 500 with auto sampler (Perkin Elmer, USA) equipped with a flame ionization detector and a fused silica capillary SGE column ( $30 \mathrm{~m} \bullet 0.32 \mathrm{~mm}$, ID $\bullet 0.25 \mathrm{~lm}$, BP20 $0.25 \mathrm{UM}$, USA). The oven temperature was brought to $140^{\circ} \mathrm{C}$ for 5 minutes, then raised to $200^{\circ} \mathrm{C}$ at a rate of $4^{\circ} \mathrm{C} / \mathrm{min}$ and to $220^{\circ} \mathrm{C}$ at a rate of $1^{\circ} \mathrm{C} / \mathrm{min}$, while the injector and the detector temperatures were set at $220^{\circ} \mathrm{C}$ and $280^{\circ} \mathrm{C}$, respectively. 
Table 1 Comparison of oil content (\%) of Soxhlet extracted and Cold pressed in Turkish sesame genotypes

\begin{tabular}{|c|c|c|c|}
\hline Genotypes & Soxhlet & Cold Press & Differrences \\
\hline Cumhuriyet-99 & 47.9 & 36.4 & 11.6 \\
\hline Tan-99 & 53.8 & 38.9 & 14.8 \\
\hline Kepsut-99 & 48.3 & 40.2 & 8.1 \\
\hline Baydar-2001 & 49 & 33.6 & 15.3 \\
\hline Muganl1-57 & 51.3 & 38.2 & 13.1 \\
\hline Orhangazi-99 & 53.3 & 39.3 & 14 \\
\hline Gölmarmara & 53.4 & 40.3 & 13.2 \\
\hline Osmanl1-99 & 52.5 & 37.1 & 15.4 \\
\hline Șanlıurfa-Siverek & 52.4 & 31.1 & 21.3 \\
\hline Diyarbakır-Merkez & 53.1 & 37.5 & 15.6 \\
\hline Kahramanmaraș & 53 & 38.7 & 14.3 \\
\hline Diyarbakır-Lice & 53.9 & 36.1 & 17.8 \\
\hline Adana-Kozan-2 & 52.9 & 42.8 & 10.2 \\
\hline Manisa-Salihli & 52 & 34.9 & 17 \\
\hline Manisa-Alașehir & 52.4 & 39.6 & 12.9 \\
\hline Adana-Ceyhan & 53.7 & 33.7 & 20 \\
\hline Antalya-Kumluca & 52.8 & 38.4 & 14.3 \\
\hline Adana-Yumurtalık & 50.9 & 36.5 & 14.4 \\
\hline Osmaniye-Kadirli & 52.4 & 40.7 & 11.8 \\
\hline Muğla-Fethiye & 51.2 & 39.3 & 12 \\
\hline Adana-Karataş & 52.7 & 41.7 & 11 \\
\hline Adana-Sarıçam & 53.6 & 40.6 & 13 \\
\hline Balıkesir-Ayvalık & 52.4 & 34.7 & 17.7 \\
\hline Aydın-Merkez & 54.7 & 37.2 & 17.6 \\
\hline Adana- Merkez & 51.4 & 37.5 & 14 \\
\hline
\end{tabular}

The sample size was $2 \mu \mathrm{l}$, and the carrier gas was controlled at 16 psi. The split used was 1:100. FAs were identified by comparing the retention times of FAME with a standard 37 component FAME mixture (Supelco). Three replicate GC analyses were performed, and the results were expressed in GC area percentage as a mean value.Statistical analysis was performed using SPSS by One-Way ANOVA method.

\section{Results and Discussion}

The results about the oil components of studied sesame genotypes revealed its dependency on the oil extraction method (Table 1). The observed variability of the seed oil content, expectedly, the averaged oil content of sesame seeds from 25 sesame genotypes was higher (average 52.2\%) with Soxhlet method compared with cold pressing (average $37.8 \%$ ). Oil contents of sesame varieties ranged from $47.9-54.7 \%$ in Soxhlet method and from $31.1-42.8 \%$ in cold press method. In this manner, results of this study are similar to the findings of Uzun et al. (2008) who reported oil content of 103 Turkish sesame landraces ranged from 41.2-62.7\%. Similar results were reported by Asghar \& Majeed (2013) and Nzikou et al. (2009). It was also reported that oil content of different sesame cultivars ranged from 50 to $69.03 \%$, with an average of $59.5 \%$ (Abdullahi et al., 1991).
In Soxhlet method, the highest and the lowest oil percentages $(54.7 \%, 47.9 \%)$ were obtained from Aydın-Merkez and Cumhuriyet-99 genotypes, respectively. Baydar et al. (1999) observed higher average oil content $(63.25 \%)$ in Turkish sesame cultivars. Variation in oil content can be attributed either to varietal factor, environmental factor, or interaction of both factors. It is reported that Moroccan sesame cultivars contained high oil percentages (over 50\%) which is a desirable trait for breeding programs to improve sesame cultivars (EL Harfi et al., 2015). Water (Alpaslan et al., 2001) and temperature also influenced the oil content of sesame (Rondanini et al., 2003). Another studies revealed that oil content was influenced under diferent conditions in diferent crops (EL Sabagh et al., 2015, EL Sabagh et al., 2016; Gulluoglu et al., 2016).

In the cold press extraction method, variety Adana-Kozan-2 was one with highest oil content among the studied genotypes. It was found that petroleum ether is a better extraction solvent (Lu et al., 2007), could be due to contributed increasing the solubilization of compounds with oxidant principles. The oxidative stability of the oil was high; it could be attributed to the presence of tocopherols, which inhibit lipid peroxidation, and of endogenous antioxidants such as sesamin and sesamolin, better known as lignans (Hemalatha, 2007). 
Table 2 Comparison of fatty acid composition $(\mathrm{g} / 100 \mathrm{~g})$ of soxhlet extracted and cold pressed in sesame genotypes

\begin{tabular}{|c|c|c|c|c|c|c|c|c|c|c|}
\hline \multirow[t]{2}{*}{ Genotypes } & \multicolumn{2}{|c|}{$\begin{array}{l}\text { Palmitic } \\
\text { Acid }\end{array}$} & \multicolumn{2}{|c|}{$\begin{array}{c}\text { Stearic } \\
\text { Acid }\end{array}$} & \multicolumn{2}{|c|}{$\begin{array}{c}\text { Arachidic } \\
\text { Acid }\end{array}$} & \multicolumn{2}{|c|}{$\begin{array}{l}\text { Oleic } \\
\text { Acid }\end{array}$} & \multicolumn{2}{|c|}{$\begin{array}{c}\text { Linoleic } \\
\text { Acid }\end{array}$} \\
\hline & Soxhlet & $\mathrm{CP}$ & Soxhlet & $\mathrm{CP}$ & Soxhlet & $\mathrm{CP}$ & Soxhlet & $\mathrm{CP}$ & Soxhlet & $\mathrm{CP}$ \\
\hline Cumhuriyet-99 & 9.816 & 10.152 & 4.948 & 4.885 & 0.577 & 0.553 & 39.021 & 39.202 & 43.819 & 43.414 \\
\hline Tan-99 & 9.633 & 10.076 & 4.945 & 4.847 & 0.584 & 0.550 & 39.183 & 39.456 & 43.762 & 43.203 \\
\hline Kepsut-99 & 9.399 & 9.603 & 5.128 & 5.073 & 0.591 & 0.572 & 40.053 & 40.223 & 43.033 & 42.765 \\
\hline Baydar-2001 & 9.660 & 10.160 & 4.816 & 4.692 & 0.523 & 0.521 & 37.847 & 37.936 & 45.295 & 44.811 \\
\hline Muganl1-57 & 9.722 & 10.087 & 4.882 & 4.805 & 0.555 & 0.548 & 38.376 & 38.821 & 44.635 & 43.919 \\
\hline Orhangazi-99 & 9.554 & 9.746 & 4.755 & 4.703 & 0.551 & 0.538 & 39.043 & 39.287 & 44.225 & 43.872 \\
\hline Gölmarmara & 9.493 & 9.849 & 5.044 & 4.949 & 0.586 & 0.580 & 38.794 & 38.919 & 44.244 & 43.862 \\
\hline Osmanl1-99 & 9.554 & 9.746 & 4.755 & 4.703 & 0.551 & 0.538 & 39.043 & 39.287 & 44.225 & 43.872 \\
\hline Șanlıurfa-Siverek & 9.504 & 9.894 & 5.120 & 5.042 & 0.606 & 0.594 & 39.317 & 39.622 & 43.597 & 43.057 \\
\hline Diyarbakır-Merkez & 9.379 & 9.726 & 4.978 & 4.843 & 0.584 & 0.571 & 39.403 & 39.293 & 43.807 & 43.722 \\
\hline Kahramanmaraș & 9.589 & 9.917 & 4.864 & 4.791 & 0.570 & 0.524 & 38.167 & 38.099 & 44.827 & 44.740 \\
\hline Diyarbakır-Lice & 9.622 & 9.200 & 4.873 & 4.751 & 0.564 & 0.549 & 39.640 & 39.881 & 43.428 & 42.932 \\
\hline Adana-Kozan-2 & 9.847 & 9.980 & 4.990 & 4.957 & 0.573 & 0.541 & 39.359 & 39.249 & 43.317 & 43.407 \\
\hline Manisa-Salihli & 9.529 & 9.109 & 4.745 & 4.613 & 0.580 & 0.557 & 41.236 & 41.674 & 43.118 & 42.233 \\
\hline Manisa-Alaşehir & 9.697 & 10.097 & 4.728 & 4.679 & 0.580 & 0.571 & 37.154 & 37.513 & 45.082 & 45.226 \\
\hline Adana-Ceyhan & 9.669 & 10.088 & 4.926 & 4.753 & 0.578 & 0.563 & 37.728 & 38.035 & 45.211 & 44.660 \\
\hline Antalya-Kumluca & 9.713 & 10.096 & 4.839 & 4.876 & 0.560 & 0.541 & 38.332 & 38.142 & 44.541 & 44.454 \\
\hline Adana-Yumurtalık & 9.548 & 9.964 & 4.822 & 4.754 & 0.531 & 0.554 & 38.185 & 38.165 & 45.080 & 44.718 \\
\hline Osmaniye-Kadirli & 9.910 & 10.053 & 4.889 & 4.088 & 0.589 & 0.571 & 37.631 & 37.767 & 45.063 & 44.897 \\
\hline Muğla-Fethiye & 9.670 & 10.258 & 4.976 & 4.858 & 0.597 & 0.562 & 40.752 & 41.184 & 42.129 & 41.899 \\
\hline Adana-Karataş & 9.467 & 9.699 & 5.078 & 5.018 & 0.551 & 0.583 & 40.232 & 40.623 & 42.837 & 42.224 \\
\hline Adana-Sarıçam & 9.763 & 10.010 & 4.834 & 4.859 & 0.601 & 0.569 & 39.224 & 39.086 & 43.629 & 43.632 \\
\hline Balıkesir-Ayvalık & 9.848 & 10.189 & 5.119 & 4.870 & 0.590 & 0.539 & 38.100 & 41.348 & 44.630 & 43.964 \\
\hline Aydın-Merkez & 9.950 & 10.559 & 4.806 & 4.699 & 0.564 & 0.535 & 37.487 & 37.526 & 45.254 & 45.012 \\
\hline Adana- Merkez & 9.648 & 10.021 & 4.800 & 4.696 & 0.567 & 0.552 & 37.545 & 37.348 & 45.538 & 45.467 \\
\hline
\end{tabular}

The oil compositions of sesame varieties were compared in five main dominated sesame fatty acid components namely palmitic, stearic, arachidic, oleic and linoleic acid (Table 2). The content of major fatty acids showed significant variation according to extraction methods (Table 3). Indeed, palmitic and oleic acids were higher in the extracted by cold press. Conversely, stearic, arachidic and linoleic acids were higher in the extracted by soxhlet.

Table 3 Statical analysis of effect of extraction methods on fatty acid composition sesame genotypes

\begin{tabular}{|c|c|c|c|c|c|c|}
\hline \multirow[t]{2}{*}{ Characters } & & \multicolumn{5}{|c|}{ ANOVA } \\
\hline & & Sum of Squares & df & Mean Square & $\mathrm{F}$ & Sig. \\
\hline \multirow[t]{3}{*}{ Palmitic acid } & Between Groups & 6.453 & 24 & .269 & 6.496 & .000 \\
\hline & Within Groups & 5.174 & 125 & .041 & & \\
\hline & Total & 11.627 & 149 & & & \\
\hline \multirow[t]{3}{*}{ Stearic acid } & Between Groups & 2.840 & 24 & .118 & 10.986 & .000 \\
\hline & Within Groups & 1.347 & 125 & .011 & & \\
\hline & Total & 4.187 & 149 & & & \\
\hline \multirow[t]{3}{*}{ Arachidic acid } & Between Groups & .043 & 24 & .002 & 9.935 & .000 \\
\hline & Within Groups & .023 & 125 & .000 & & \\
\hline & Total & .066 & 149 & & & \\
\hline \multirow[t]{3}{*}{ Oleic acid } & Between Groups & 172.385 & 24 & 7.183 & 49.570 & .000 \\
\hline & Within Groups & 18.113 & 125 & .145 & & \\
\hline & Total & 190.497 & 149 & & & \\
\hline \multirow[t]{3}{*}{ Linoleic acid } & Between Groups & 125.207 & 24 & 5.217 & 97.467 & .000 \\
\hline & Within Groups & 6.691 & 125 & .054 & & \\
\hline & Total & 131.898 & 149 & & & \\
\hline
\end{tabular}


Among various reported saturated fatty acids, palmitic and stearic acids were the predominant saturated fatty acids of sesame oil with a range of $9.38-10.56$ and $4.73-5.12 \%$, respectively (Table 2 ).

Arachidic acid was a minor constituent of sesame oil with a range of $0.52-0.59 \%$. Oleic and linoleicacids are the major fatty acids of sesame oil (Arslan et al., 2007; Uzun et al., 2008), and they are found to be present in large proportion in the oils of all genotypes. Oleic acid content of sesame oil ranged from 37.15 to $41.67 \%$. While, the highest oleic acid content was determined in the oil of Manisa-Salihli genotype, the lowest content was determined in the oil of genotype Manisa-Alaşehir. Linoleic acid varied between 41.9 to $45.54 \%$ (Muğla-Fethiye, Adana-Merkez, respectively). Thus, linoleic acid content of sesame oil was found to be higher than that of oleic acid. The oleic and linoleic acids were the main fatty acids. The high amount of unsaturated fatty acid with a value of $80 \%$ of total fatty acids increases the quality of sesame oil (Chung et al., 1995). In present study all the varieties have an amount of oleic and lineloic acid with the value of over $80 \%$. Bozan \& Temelli (2002), the conventional extraction method using organic solvents giving a higher extraction yield.

\section{Conclusions}

Based on the results of this study, the fatty acid composition of sesame oil varied among Turkish sesame genotypes and there were significant differences observed among the Turkish sesame genotypes for fatty acid composition of oil obtained by two extraction methods.

\section{Conflict of interest}

Authors would hereby like to declare that there is no conflict of interests that could possibly arise.

\section{References}

Abdullahi Y, Adeniyi MO, Ihekwuemere CA (1991) Countdown to senior secondary certificate exams in Agriculture Science.Evans Brothers, Nigeria.p.150.

AOAC (1984) Official Methods of Analysis, 14th Ed., Assoc. of Official Analytical Chemists, Washington,DC.

AlamSarkar MN, Salim M, Islam N, Rahman MM (2007) Effect of sowing date and time characters of sesame (Sesamum indicum L.) seed. International Journal Sustainable Crop Production 2: 31-35.

Alpaslan M, Boydak E, Demircim M (2001) Protein and oil composition of soybean and sesame seed grown in the Harran (GAP) area of Turkey. Session 88B, Food Chemistry: Food Composition and Analysis.IFT Annual Meeting-New Orleans.

Arslan Ç, Uzun B, Ülger S, Çagirgan MI (2007) Determination of oil content and fatty acid compositions of sesame mutants suited for intensive management conditions. Journal of the American Oil Chemists' Society 84: 917920.http://dx.doi:10.1007/s11746-007-1125-6.

Asghar A, Majeed MN (2013) Chemical characterization and fatty acid profile of different sesame verities in Pakistan. American Journal Science and Industrial Research 4: 540545.http://dx.doi:10.5251/ajsir.2013. 4.6.540.545.

Bavec F, Mlakar SG, Rozman C, Bavec M (2007) Issues in New Crops and New Uses. In: Janick J, Whipkey A (Eds.), ASHS Press. Alexandria,VA. pp.185-189.

Baydar H, Turgut I, Turgut K (1999) Variation of certain characters and line selection for yield, oleic and linoleic acid in the Turkish sesame (Sesamum indicum L.) populations. Tropical Journal of Agriculture and Forestry 23: 431-441.

Bozan B, Temelli F (2002) Supercritical CO2 extraction of flaxseed. Journal of the American Oil Chemists Society 79 : 231.

Chung CH, Yee YJ, Kim DH, Kim HK, Chung DS (1995) Changes of lipid, protein, RNA, and fatty acid composition in developing sesame (Sesamum indicumL.) seeds. Plant Science 109: 237-243. http://dx.doi:10.1016/0168-9452(95)04160-V.

Corso MP, Klen MF, Silva EA, Filho LC, Santos JN, Freitas LS, Dariva C (2010) Extraction of sesame seed (Sesamun indicum L.) oil using compressed propane and supercritical carbon dioxide. The Journal of Supercritical Fluids 52: 56. http://dx.doi.org/10.1016/j.supflu.2009.11.012.

EL-Harfi M, Nabloussi A, Rizki H, Latrache H, Ennahli S, Hanine H (2015) Biochemical Assessment of Moroccan Sesame (Sesamum indicum) Genotypes. Journal of Multidisciplinary Enginneering Science and Technology 2: 1105-1115.

El Sabagh A, Omar A, Barutçular C, Saneoka H (2016) Role of integrated use of nitrogen fertilizer sources in improving seed quality of canola (Brassica napus L.). Turkish Journal of Agriculture - Food Science and Technology 4 : PP. 73-78.

EL Sabagh A ,Sorour S, Omar A, IslamMS, Ueda A, Saneoka H, Barutçular C (2015) Soybean (Glycine max L.) Growth Enhancement under Water Stress Conditions. International Conference on Chemical, Agricultural and Biological Sciences, (CABS-2015) September, 4-5, 2015 Istanbul (Turkey), pp. 148-152.

Ghafoorunissa (1994) Dietary fats/oils and heart diseases. In: Prasad, M.V.R. (ed). Sustainability in oil seeds. Indian Society of Oil Seeds Research, Hyderabad, India. pp. 486-490.

Gogolewski M, Nogala-Kałucka M, Szeliga M (2000) Changes of tocopherol and fatty acid contents in rapeseed oil during refining. European Journal of Lipid Science and Technology 
120:618-

623.http://dx.DOI:10.1002/14389312(200010)102:10<618::AI

D-EJLT618>3.0.CO;2-6.

Gulluoglu L, Bakal H, Onat B, EL Sabagh A , Arioglu H (2016) Characterization of peanut (Arachis hypogaea L.) seed oil and fatty acids composition under different growing season under mediterranean environment. Journal of Experimental Biology and Agricultural Sciences 5 (Suppl.) (In Press).

Guillen MD, Goicoechea E (2008) Formation of oxygenated $\alpha, \beta$-unsaturated aldehydes and other toxic compounds in sunflower oil oxidation at room temperature in closed receptacles.Food Chemistry 111:157.http://dx.doi.org/10.1016/j.foodchem.2008. 03.052.

Hemalatha GS (2007) Sesame lignans enhance the thermal stability of edible vegetable oils. Food Chemistry 105: 1076.

Koski A, Pekkarinen S, Hopia A, Wahala K (2003) Processing of rapeseed oil: effects on sinapic acid derivative content andoxidative stability. European Food Research Technology 217: 110-114. http://dx.doi.10.1007/s00217-003-0721-4.

Lu B, Zhang Y, Xiaoqin W, Jiayi S (2007) Separation and determination of diversiformphytosterols in foodmaterialsusingsupercriticalcarbondioxideextraction and ultraperformanceliquidchromatography-

atmosphericpressurechemicalionization-massspectrometry.

AnalyticaChimica Acta : $588: 50$.

Martin JH, Leonard WH (1964) Principles of Field Crop Production. MacMillan Co. New York, USA. pp. 1039-1040.

Nadeem R, Iqbal A, Zia MA, Anwar F, Shahid SA, Mahmood Z, Shafeeq A, Akhtar N (2015) Effect of Cold-Pressing and Soxhlet Extraction on the Physico- Chemical Attributes of
Sunflower (Helianthus annuus L.) Seed Oil. International Journal of Clinical \& Biological Sciences 7: 41-46.

Namiki M (1995) The chemistry and physiological functions of sesame. Food Reviews International 1: 281-329.

Nzikou JM, Matos L, Bouanga-Kalou G, Ndangui CB, Pambou-Tobi NPG, Kimbonguila A, Silou Th, Linder M, Desobry S (2009) Chemical composition on the seeds and oil of sesame (Sesamum indicum L.) Grown in Congo Brazzaville. Advance Journal of Food Science and Technology $1: 6-11$.

Ozogul Y, Polat A, Ucak I, Ozogul F (2011) Seasonal fat and fatty acids variations of seven marine fish species from the Mediterranean Sea. European Journal of Lipid Science and Technology $113 \quad$ : $1491-1498 . \quad$ http://dx.doi: 10.1002/ejlt.201000554.

Pathak N, Rai AK, Kumari R, Bhat KV (2014) Valueaddition in sesame: A perspective on bioactive components for enhancing utility and profitability. Pharmacogn Review 8 : 147-155.doi:10.4103/0973-7847.134249.

Rondanini D, Savin R, Hall AJ (2003) Dynamics of fruit growth and oil quality of sunflower (Helianthus annuus L.) exposed to brief intervals of high temperature during grain filling. Field Crops Research 83: 7990.http://dx.doi:10.1016/S0378-4290(03)00064-9.

Uzun B, Arslan C, Furat S (2008) Variation in fatty acid compositions, oil content and oil yield in a germplasm collection of sesame (Sesamum indicumL.). Journal of the American Oil Chemmists' Society 85 : 1135-1142. http://dx.doi: 10.1007/s11746-008-1304-0.

Weiss EA (2000) Oilseed Crops. 2nd ed., Blackwell Science, Oxford, pp. 131-164. 